Article

\title{
Sensitivity Analysis of Alisma plantago-aquatica L., Cyperus difformis L. and Schoenoplectus mucronatus (L.) Palla to Penoxsulam
}

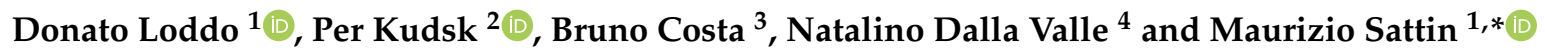 \\ 1 Institute of Agro-Environmental and Forest Biology-CNR, Agripolis, 35020 Legnaro, Italy; \\ donato.loddo@ibaf.cnr.it \\ 2 Department of Agroecology, Aarhus University, Forsøgsvej 1, DK-4200 Slagelse, Denmark; \\ per.kudsk@agro.au.dk \\ 3 DAFNAE, University of Padova, Agripolis, 35020 Legnaro, Italy; bruno-costa@alice.it \\ 4 Regional Biology Program Leader, Dow Agrosciences Italia, 40126 Bologna, Italy; DALLAVALLE@dow.com \\ * Correspondence: maurizio.sattin@ibaf.cnr.it; Tel.: +39-049-8272820
}

Received: 3 August 2018; Accepted: 5 October 2018; Published: 8 October 2018

\begin{abstract}
Determining the intra-specific variability of response to a given herbicide is important for monitoring the possible shifts in the sensitivity of weed populations. This study describes the responses of populations of Alisma plantago-aquatica, Cyperus difformis, and Schoenoplectus mucronatus from Italy, Greece, Portugal, and Spain to penoxsulam, an acetolactate synthase (ALS) inhibitor widely used in rice. To evaluate previously evolved resistance to ALS inhibitors, sensitivity to azimsulfuron and bensulfuron-methyl was assessed. Dose-response experiments with penoxsulam were performed in a greenhouse simulating paddy rice field conditions. Log-logistic dose-response curves were used to estimate the $\mathrm{ED}_{50}, \mathrm{ED}_{80}, \mathrm{ED}_{90}$ and $\mathrm{GR}_{50}, \mathrm{GR}_{80}$, and $\mathrm{GR}_{90}$. To calculate the average $\mathrm{ED}$ and GR and assess the intra-specific variability, an artificial resampling method was performed. Populations ALSPA 0364, 0365, 0469, 0470, 0471; SCPMU 0371, 0475, 0267; CYPDI 0013, 0431, 0432, 0433 appeared to be resistant to sulfonylureas, while a higher sensitivity to penoxsulam was observed, while populations ALSPA 0363, CYPDI 0223 and SCPMU 9719 proved to be cross-resistant. Regardless of species, $\mathrm{ED}_{90}$ of susceptible populations were below penoxsulam label dose $\left(40 \mathrm{~g}^{\mathrm{ai}} \mathrm{ha}^{-1}\right)$ while they reached values higher than $320 \mathrm{~g}_{\text {ai ha }}{ }^{-1}$ for resistant populations. Average $\mathrm{GR}_{50}$ were generally lower than $\mathrm{ED}_{50}$. Sensitivity variability among susceptible populations is relatively low, allowing for discrimination between susceptible and resistant populations, and previously evolved resistance to sulfonylureas can influence sensitivity to penoxsulam.
\end{abstract}

Keywords: Alisma plantago-aquatica; Cyperus difformis; Schoenoplectus mucronatus; ALS inhibitors; resistance evolution; target-site resistance; cross-resistance; rice

\section{Introduction}

Rice is grown on about 500,000 ha in Europe, with Italy being the main producer cultivating around 240,000 ha. Weeds are the main pest category for rice, especially in paddy conditions; so, chemical weed control is an essential component of crop management. Intensive use of herbicides with the same site of action (SoA), mainly inhibitors of acetolactate synthase (ALS), is a common characteristic of weed management in rice. This situation strongly increases the risk of selecting herbicide resistant biotypes, which have constantly increased over the last 20 years [1,2]. Since the mid-1990s, several rice weed species have evolved resistance to ALS inhibitors in Europe, United States of America (USA), and Korea [3-7]. More specifically, it is estimated that at least half of the area cultivated with rice in Italy has been infested with ALS-resistant weed biotypes [2]. 
Alisma plantago-aquatica L., Cyperus difformis L., and Schoenoplectus (or Scirpus) mucronatus (L.) Palla were the first species involved [3,4,8], followed by Echinochloa crus-galli (L.) Beauv [9], and then weedy rice infesting imazamox-tolerant rice varieties [10]. Monitoring a possible shift in the sensitivity of weeds to a given herbicide after its introduction on the market is crucial to reduce the risk of resistance evolution and the determination of intra-specific variability of response, i.e., the baseline sensitivity, of key-target species is the necessary starting point. This is particularly valuable when the rate of decrease of sensitivity and resistance evolution is rather slow, i.e., when a non-target site resistance mechanism is involved. The European and Mediterranean Plant Protection Organisation [11] defines baseline sensitivity as the mean of the variability of target species sensitivity before the commercial introduction of an active substance. It has also been proven that a weed population is often resistant not only to the main selecting agent, but also to herbicides having the same SoA [12,13], even before they were marketed. Therefore, if a new herbicide having a certain SoA is introduced in a cropping system where the selection pressure exerted by other herbicides with the same SoA has already been acting, the baseline approach is not correct; a sensitivity analysis should instead be performed to elucidate the efficacy of the new herbicide in various environmental and agronomic conditions and with different weed populations [14]. This is particularly important for weed species where resistance is widespread, such as A. plantago-aquatica, C. difformis, and S. mucronatus to ALS inhibitors. It has been stressed that the lack of new herbicide SoA [15] together with the loss in some countries of older ones with unique SoA due to stricter regulations [16], make the preservation of the efficacy of available herbicides a top priority. Determination of baselines or sensitivity analysis to widely-used herbicides can significantly contribute to this, as well as provide useful data in relation to the possible reduction of herbicide doses $[14,17]$. However, their determination through large dose-response experiments including many populations is costly and time-consuming, so available data are scarce.

Penoxsulam is a triazolopyrimidine sulphonamide ALS inhibitor for post-emergence application in dry and water-seeded rice and a leading rice herbicide worldwide [18]. It is very active against A. plantago-aquatica, C. difformis, and S. mucronatus, as well as controlling other important rice weed species such as Echinochloa spp. [19]. However, its efficacy can be influenced in situations of cross and/or multiple resistance, i.e., by the selection exerted by other herbicides with the same SoA $[9,20]$. This research determines the response to the ALS-inhibitor penoxsulam of 12 populations of $C$. difformis and A. plantago-aquatica as well as 11 populations of S. mucronatus collected in Italy, Greece, Portugal, and Spain. These species were selected for this study for their specificity as paddy rice weeds and agronomic importance throughout Europe, also given the widespread presence of biotypes that are resistant to other ALS inhibitors, such as the sulfonylureas. Aims were (a) to perform a sensitivity analysis and explore the variability of response to penoxsulam of three important rice weed species; and, (b) to propose a method to obtain baseline sensitivity information from a limited number of susceptible populations.

\section{Materials and Methods}

\subsection{Seed Collection}

Seeds of 12 populations of $C$. difformis (Bayer code: CYPDI, smallflower umbrella sedge), 12 of A. plantago-aquatica (Bayer code: ALSPA, common waterplantain), and 11 of S. mucronatus (Bayer code: SCPMU, ricefield bulrush) were collected in southern European countries where rice is regularly cultivated (Italy, Spain, Portugal and Greece). Given that more than $50 \%$ of the European rice cultivated area is in Italy, more than $50 \%$ of the C. difformis and A. plantago-aquatica populations were sampled there. Only Italian populations of $S$. mucronatus were included in the experiments, since no resistant populations of this species are reported in other European countries [1]. Sampling was partly done in rice fields left herbicide untreated or field margins and partly in sites with widely differing herbicide history including fields where ALS inhibitors had never been used. Within each site, seeds were collected from at least 50 mother plants in different parts of the fields to obtain a 
seed batch representative of the intra-population variability. Some known ALS-resistant biotypes, i.e., populations 0363 of A. plantago-aquatica, 0013 and 0223 of C. difformis and 9719 and 0267 of S. mucronatus, were also included in the experiment as ALS-resistant checks. The samples were collected before penoxsulam was commercialized, however other ALS inhibitors (SU) had been used in previous years. Some populations, i.e., 0367, 0368, 0473, 0474, and 0475 of A. plantago-aquatica, 0439 and 0440 of $C$. difformis and 0478 of $S$. mucronatus were deliberately collected in areas where no ALS inhibitor had been used before to assess whether previous exposure to a herbicide with this SoA could affect sensitivity to penoxsulam. Information regarding origin and any previous exposure to ALS inhibitors of each population is reported in Table 1.

Table 1. Country of origin, collection site and available information on previous exposure to acetolactate synthase (ALS)-inhibitors of the different populations of Alisma plantago-aquatica (ALSPA), Cyperus difformis (CYPDI) and Schoenoplectus mucronatus (SCPMU).

\begin{tabular}{|c|c|c|c|c|}
\hline Species & Population Code & Origin & Collection Site & $\begin{array}{l}\text { Previous Direct Exposure } \\
\text { to ALS Inhibitors }\end{array}$ \\
\hline \multirow[t]{12}{*}{ ALSPA } & 0363 & Italy & Rice field & - \\
\hline & 0364 & Spain & Rice field & - \\
\hline & 0365 & Italy & Rice field & - \\
\hline & 0366 & Spain & Rice field & - \\
\hline & 0367 & Italy & Ditch & No \\
\hline & 0368 & Italy & Rice field & No or sporadic \\
\hline & 0469 & Spain & Rice field & Yes \\
\hline & 0470 & Italy & Rice field & - \\
\hline & 0471 & Portugal & Rice field & - \\
\hline & 0473 & Italy & Uncultivate area & No or sporadic \\
\hline & 0474 & Italy & Ditch & No \\
\hline & 0475 & Italy & Rice field & No or sporadic \\
\hline \multirow[t]{12}{*}{ CYPDI } & 0013 & Italy & Rice field & - \\
\hline & 0325 & Italy & Rice field & - \\
\hline & 0326 & Spain & Rice field & Yes \\
\hline & 0327 & Italy & Rice field & - \\
\hline & 0328 & Spain & Rice field & Yes \\
\hline & 0223 & Italy & Rice field & Yes \\
\hline & 0431 & Spain & Rice field & Yes \\
\hline & 0432 & Spain & Rice field & Yes \\
\hline & 0433 & Italy & Rice field & Yes \\
\hline & 0434 & Greece & Rice field & - \\
\hline & 0439 & Italy & Rice field & No or sporadic \\
\hline & 0440 & Italy & Rice field & No or sporadic \\
\hline \multirow[t]{11}{*}{ SCPMU } & 9719 & Italy & Rice field & Yes \\
\hline & 0368 & Italy & Rice field & - \\
\hline & 0369 & Italy & Rice field & - \\
\hline & 0370 & Italy & Rice field & - \\
\hline & 0371 & Italy & Rice field & - \\
\hline & 0267 & Italy & Rice field & Yes \\
\hline & 0472 & Italy & Rice field & - \\
\hline & 0473 & Italy & Rice field & - \\
\hline & 0474 & Italy & Rice field & - \\
\hline & 0475 & Italy & Rice field & - \\
\hline & 0478 & Italy & Rice field & No or sporadic \\
\hline
\end{tabular}

- indicates no precise information available.

\subsection{Plant Material and Growing Conditions}

Different treatments were performed to break dormancy and promote the germination of the three species. Seeds of $C$. difformis were stratified at $4 \mathrm{C}$ on moistened filter paper in Petri dishes for 
15 days and then immersed for $10 \mathrm{~min}$ in a sodium hypochlorite solution $\left(10 \mathrm{~mL} \mathrm{~L}^{-1}\right)$ to prevent fungi development. Seeds were finally put in Petri dishes filled with an agar substrate $\left(60 \mathrm{mg} \mathrm{g}^{-1}\right)$ containing $\mathrm{KNO}_{3}\left(20 \mathrm{mg} \mathrm{g}^{-1}\right)$ and incubated at a thermal regime of 25 (light)/15 (dark) C with a $12 / 12 \mathrm{~h}$ (light/dark) photoperiod. Seedlings were transplanted at the cotyledon stage into Styrofoam containers each with 24 cavities (diameter $60 \mathrm{~mm}$ and $100 \mathrm{~mm}$ deep) filled with a mixed substrate (silt loam soil 62\%, sand 35\%, and peat 3\%). A longer chilling treatment (30 days) at $4 \mathrm{C}$, as reported by Scarabel et al. [21], was adopted for dormancy-breaking of S. mucronatus seeds that were then directly sown in Styrofoam containers. Seeds of A. plantago-aquatica were sown in plastic trays with a perforated bottom and filled with a layer of $2-3 \mathrm{~cm}$ of peat. The trays were left floating on water for 20 days to maintain the substrate wet and achieve good germination. Seedlings were then transplanted into Styrofoam containers. Seedlings of the three species were produced from the collected seed batches and then placed in Styrofoam containers each with 12 cavities (diameter $60 \mathrm{~mm}$ and $100 \mathrm{~mm}$ deep) filled with a mixed substrate (silt loam soil $62 \%$, sand $35 \%$, and peat $3 \%$ ). Two seedlings were maintained in each cavity and so the experimental unit was made up of 24 plants. In order to simulate the environmental conditions of rice fields, the containers were placed in a greenhouse and left floating in plastic trays filled with water. Two days before the herbicide application, the containers were completely submerged and then remained in this condition for the rest of the experiment. Temperatures in the greenhouse were maintained throughout the experiments in a range similar to paddy rice field conditions in the period of herbicide applications. Daily temperature fluctuations ranged from an average minimum of $14.3 \mathrm{C}$ (range 7.5-23.0 C) during the night to an average maximum of $33.1 \mathrm{C}$ (range 12.0-44.0 C) during the day.

\subsection{Preliminary Screenings}

Given that several populations had previously been exposed to other ALS-inhibiting herbicides, a separate preliminary screening was conducted with each species according to the methodology described by Sattin et al. [22] to assess the sensitivity of the populations to penoxsulam, as well as to two other ALS inhibitors widely used in rice fields in the areas where the studied populations were collected, i.e., azimsulfuron and bensulfuron-methyl. Population 0363 of A. plantago-aquatica was tested only with bensulfuron-methyl due to poor germination and consequently reduced number of seedlings available for the experiment. Azimsulfuron (Gulliver ${ }^{\circledR}, 600 \mathrm{~g}$ ai kg ${ }^{-1}$, Cheminova Agro Italia, Bergamo, Italy) and bensulfuron-methyl (Londax $60 \mathrm{DF}^{\circledR}, 600 \mathrm{~g}$ ai kg${ }^{-1}$, Du Pont de Nemours Italiana, Milano, Italy) were applied at the label dose corresponding to 20 and $60 \mathrm{~g}$ ai ha ${ }^{-1}$, respectively, while penoxsulam (ViperTM, $20 \mathrm{~g}_{\text {ai L }}{ }^{-1}$, Dow Agrosciences Italia, Bologna, Italy) was applied at half the label dose, i.e., $20 \mathrm{~g}$ ai ha ${ }^{-1}$, to identify populations that could be at an initial phase of developing resistance. A surfactant (Trend $90^{\circledR}$, isodecyl alcohol ethoxylate $900 \mathrm{~g} \mathrm{~L}^{-1}$, Du Pont de Nemours Italiana, Milano, Italy) was added to azimsulfuron solution at the dose of $1 \mathrm{~mL} \mathrm{~L}^{-1}$. Herbicide application was performed on plants at the 2-4 true leaves stage, corresponding to stage 12-14 of the extended BBCH scale [23]. Applications were made using a precision bench sprayer with a boom equipped with three flat fan hydraulic nozzles (TeeJet XR11002-VK, Glendale Heights, IL, USA). Nozzles were $0.5 \mathrm{~m}$ apart and delivered a spray volume of $300 \mathrm{~L} \mathrm{ha}^{-1}$, applied at a pressure of $215 \mathrm{kPa}$ and speed of $0.75 \mathrm{~m} \mathrm{~s}^{-1}$. Experimental layout was a completely randomized design with three replicates of 24 plants each. Plants were counted just before the herbicide application and plant survival was determined 4-5 weeks after treatment (WAT) and expressed as percentage of the plants observed before the treatment for that specific experimental unit. Plants showing no active growth, i.e., no size increase or new leaves production, regardless of color, were considered to be dead. Fresh weight of above-ground biomass was recorded for each replicate and expressed as percentage of the average fresh weight biomass of the untreated replicates of the corresponding population. Means and standard errors were calculated for plant survival and the fresh weight above-ground biomass of each combination population $\mathrm{x}$ herbicide. Populations that had a plant survival percentage above $20 \%$ when treated with one of the tested herbicides at label dose were considered to be resistant [24]. The experiments were repeated twice. 


\subsection{Dose-Response Experiments}

Separate dose-response experiments were conducted for each species. All of the populations were included in these experiments to assess their sensitivity to penoxsulam. Following the same procedures used in the preliminary experiment, described above, plants were treated with a range of penoxsulam doses $\left(2.5,5,10,20,40,80\right.$, and $160 \mathrm{~g}$ ai ha ${ }^{-1}$ covering from $1 / 16$ to 4 times the label dose). Additional doses of 1.25 and $320 \mathrm{~g}$ ai ha ${ }^{-1}$ were included for the populations that exerted a very high or low sensitivity to ALS inhibitors according to the preliminary experiment, respectively. Untreated controls were also included for all populations. The experimental layout was a completely randomized design with three replicates of 24 plants for each treatment. Plant survival and fresh weight were estimated at 4 WAT while using the same procedure as in the preliminary experiment. Means and standard errors were estimated for plant survival and fresh weight of each treatment. The fresh weight and survival data were used to estimate $\mathrm{ED}_{50}, \mathrm{ED}_{80}$, and $\mathrm{ED}_{90}$, i.e., the effective dose required to kill $50 \%, 80 \%$ and $90 \%$ of the treated plants, and $\mathrm{GR}_{50}, \mathrm{GR}_{80}$, and $\mathrm{GR}_{90}$, i.e., the effective dose required to obtain a growth reduction of $50 \%, 80 \%$ and $90 \%$ in comparison with the untreated plants for each population using a log-logistic model [25] with the following equations:

$$
\begin{gathered}
U_{i j}=\frac{D}{1+\exp \left(2 b_{i}\left(\log \left(\mathrm{ED}_{50 i}\right)-\log \left(z_{i j}\right)\right)\right)} \\
U_{i j}=\frac{D}{1+\exp \left(2 b_{i}\left(\log \left(\mathrm{ED}_{80 i}\right)+0.6930 / b_{i}-\log \left(z_{i j}\right)\right)\right)} \\
U_{i j}=\frac{D}{1+\exp \left(2 b_{i}\left(\log \left(\mathrm{ED}_{90 i}\right)+1.099 / b_{i}-\log \left(z_{i j}\right)\right)\right)}
\end{gathered}
$$

where $U_{i j}$ denotes fresh weight or survival at the $j$ th dose of the $i$ th penoxsulam preparation (zij), $\mathrm{D}$ denotes the upper asymptote. i.e., the average of fresh weight/survival at infinite doses of the untreated plants and $b$ is slope of the dose response in the inflection point. Since fresh weight for each replicate was expressed as percentage of the average fresh weight of untreated plants of the corresponding population, the corresponding upper asymptote was set to $100 \%$. A common D value for all penoxsulam preparations was assumed, while the $\mathrm{ED}_{50}, \mathrm{ED}_{80}, \mathrm{ED}_{90}$, and $\mathrm{b}$ parameters were estimated for each dose response curve. $\mathrm{ED}_{50}, \mathrm{ED}_{80}$, and $\mathrm{ED}_{90}$ doses were compared using a $t$-test. SAS 9.1 software (SAS Institute Inc., Cary, NC, USA) was used to perform this analysis. Given that the number of susceptible populations of each species was rather low, to calculate the average $\mathrm{ED}_{50}$, $\mathrm{ED}_{80}$ of fresh biomass and plant survival and to assess the range of intra-specific variability (95\% confidence interval) for the three species, an artificial re-sampling method (with 5000 samples) was performed with a bootstrap procedure [26] using a Microsoft Excel 2010 macro (Microsoft, Redmond, WA, USA). Any populations that proved to be resistant or even partially resistant were not included in the analysis.

\section{Results}

\subsection{Preliminary Screenings}

Bartlett's test revealed that the two runs of the experiment conducted for each species did not differ, so the data were averaged over the six replicates (three for each run). A wide variability of sensitivity to ALS inhibitors was observed among the populations for all three species regarding both percentages of plant survival and fresh biomass, which gave similar results (Spreadsheet S1). Standard errors for A. plantago-aquatica were rather high, especially for the fresh weight data (Figure 1). This was likely a consequence of the extremely small seeds and very slow seedling establishment. The efficacy of the two SUs was very good on still susceptible populations of $C$. difformis and S. mucronatus, whereas none of the A. plantago-aquatica populations were completely controlled by these herbicides, not even those collected in sites where SU had never or sporadically been used (see Table 1 and Figures 1-3). 
As well as the resistant checks (ALSPA 0363, SCPMU 9719, CYPDI 0013 and 0267), other populations that were collected in Italy as well as in Spain and Portugal appeared to be clearly resistant to both sulfonylureas, i.e., ALSPA 0364, 0365, 0469, 0470, and 0471 (Figure 1), CYPDI 0013, 0223, 0431, 0432, and 0433 (Figure 2), and SCPMU 9719, 0371, 0267, and 0475 (Figure 3). In general, a higher sensitivity to penoxsulam in comparison with the two SUs was observed for the three species. The application at half of the full label dose of penoxsulam (i.e., $20 \mathrm{~g}_{\text {ai ha }}{ }^{-1}$ ) achieved a higher or equal control level than the application of the full label dose of azimsulfuron and bensulfuron-methyl, even on most of the ALS resistant populations (Figures 1-3). This effect is particularly notable for S. mucronatus (Figure 3). However, significant percentages of plants surviving the penoxsulam application were observed for ALSPA populations 0364, 0365, 0469, 0470, and 0471 (Figure 1), CYPDI 0013, 0223, 0431, 0432, and 0433 (Figure 2), SCPMU 9719 and 0475 (Figure 3). These populations can therefore be considered cross-resistant to penoxsulam, azimsulfuron, and bensulfuron-methyl, or at least as shifting towards this situation.

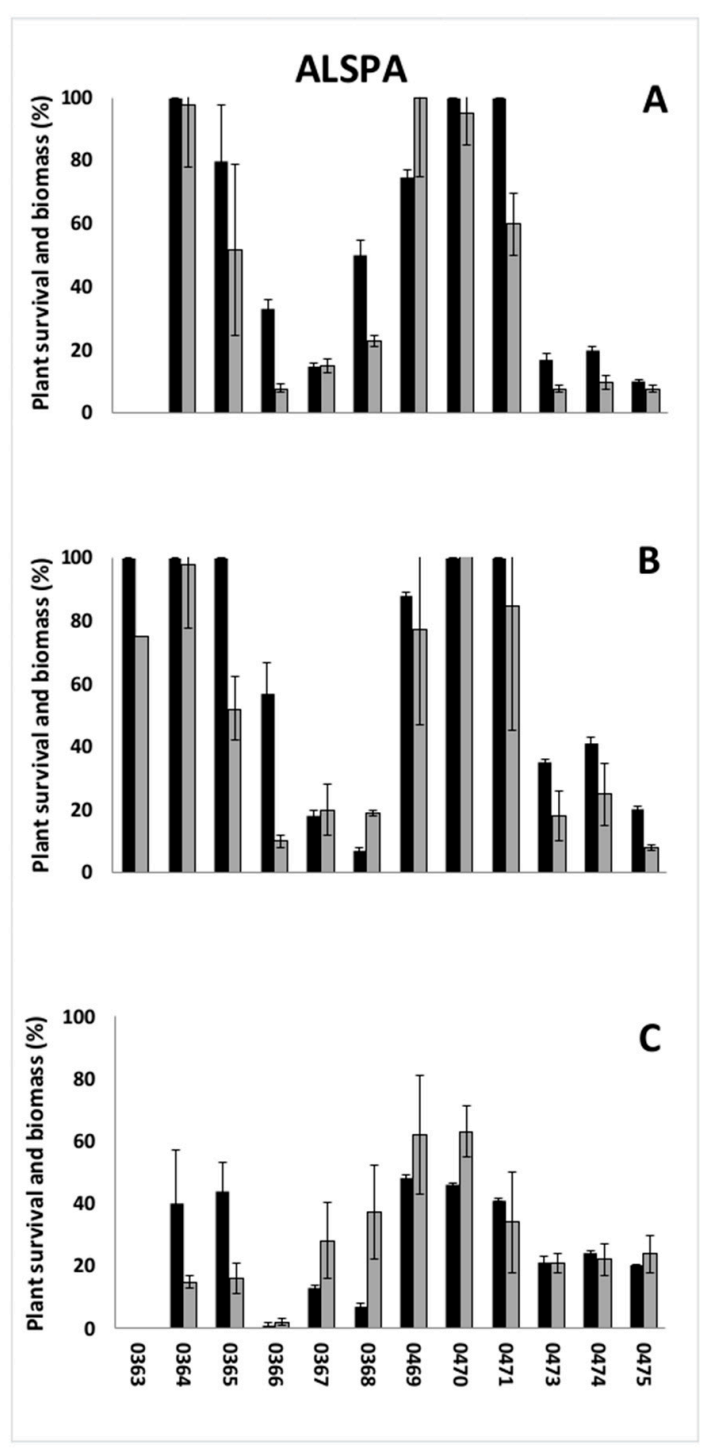

Figure 1. Sensitivity of populations of Alisma plantago-aquatica (ALSPA) to three ALS inhibitors, azimsulfuron (A), bensulfuron-methyl (B), applied at full label dose corresponding to 20 and $60 \mathrm{~g}$ ai $\mathrm{ha}^{-1}$ respectively and penoxsulam (C), applied at half the full label dose, corresponding to $20 \mathrm{~g}$ ai ha ${ }^{-1}$. Population 0363 is an ALS-resistant check. Values of survival (black bars) and biomass (grey bars) are expressed as percentage of the untreated control. Vertical bars represent standard errors. Due to low germination obtained for population 0363 , only the screening with bensulfuron-methyl was conducted. 

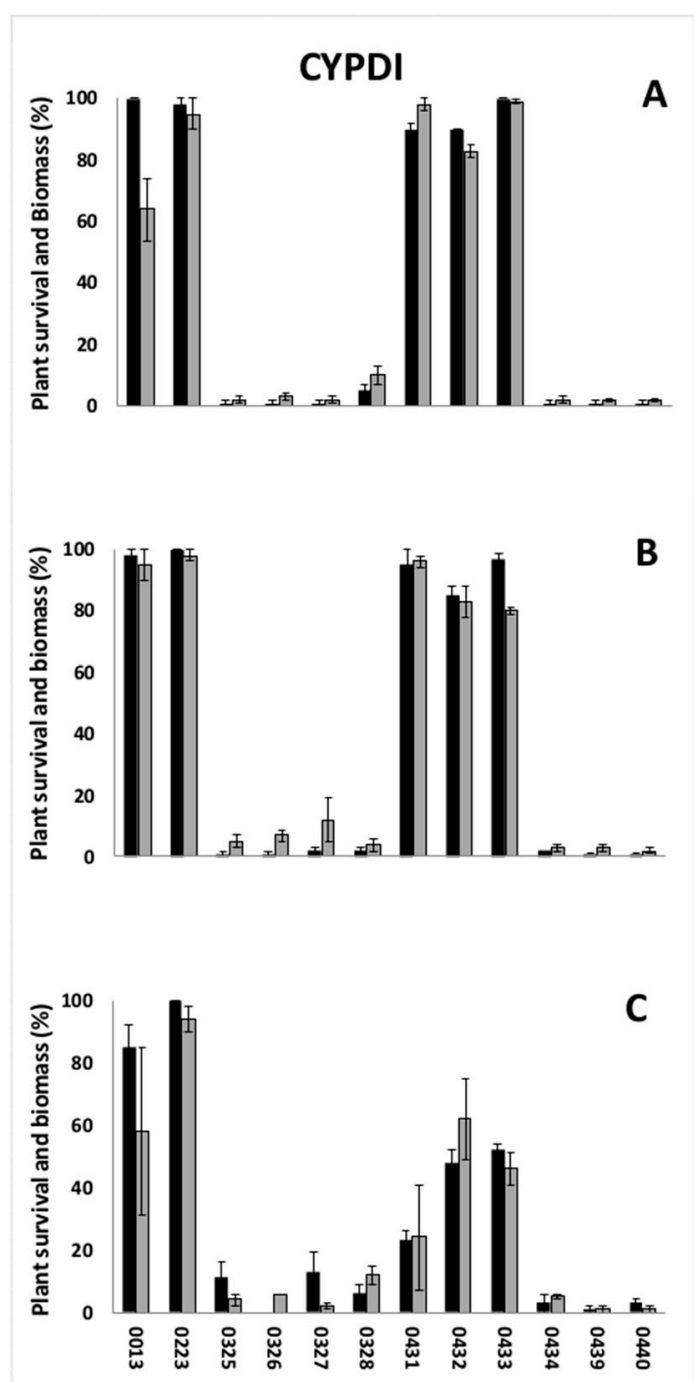

Figure 2. Sensitivity of populations of Cyperus difformis (CYPDI) to three ALS inhibitors, azimsulfuron (A), bensulfuron-methyl (B), applied at full label dose corresponding to 20 and $60 \mathrm{~g}$ ai ha ${ }^{-1}$, respectively, and penoxsulam (C), applied at half the full label dose, corresponding to $20 \mathrm{~g} \mathrm{ai} \mathrm{ha}^{-1}$. Populations 0013 and 0223 are ALS-resistant checks. Values of survival (black bars) and biomass (grey bars) are expressed as percentage of the untreated control. Vertical bars represent standard errors.

\subsection{Dose-Response Experiments}

Although the populations that are resistant to SUs were included in the dose-response experiment, and some of them were still adequately controlled by the recommended field dose of penoxsulam, they were not considered for the estimation of intra-specific variability, because most of them appeared to be shifting towards a less susceptible status. Three of the SU-resistant checks (i.e., ALSPA 0363, CYPDI 0223, and SCHMU 9719) were confirmed to be highly cross-resistant to penoxsulam, whereas others (i.e., ALSPA 0365, 0469, 0470, and 0471; CYPDI 0013, 0431, 0432, and 0433; SCPMU 0267 and 0475) were partially controlled by the triazolopyrimidines sulfonamides (Figures 4-6) (Spreadsheet S1). 


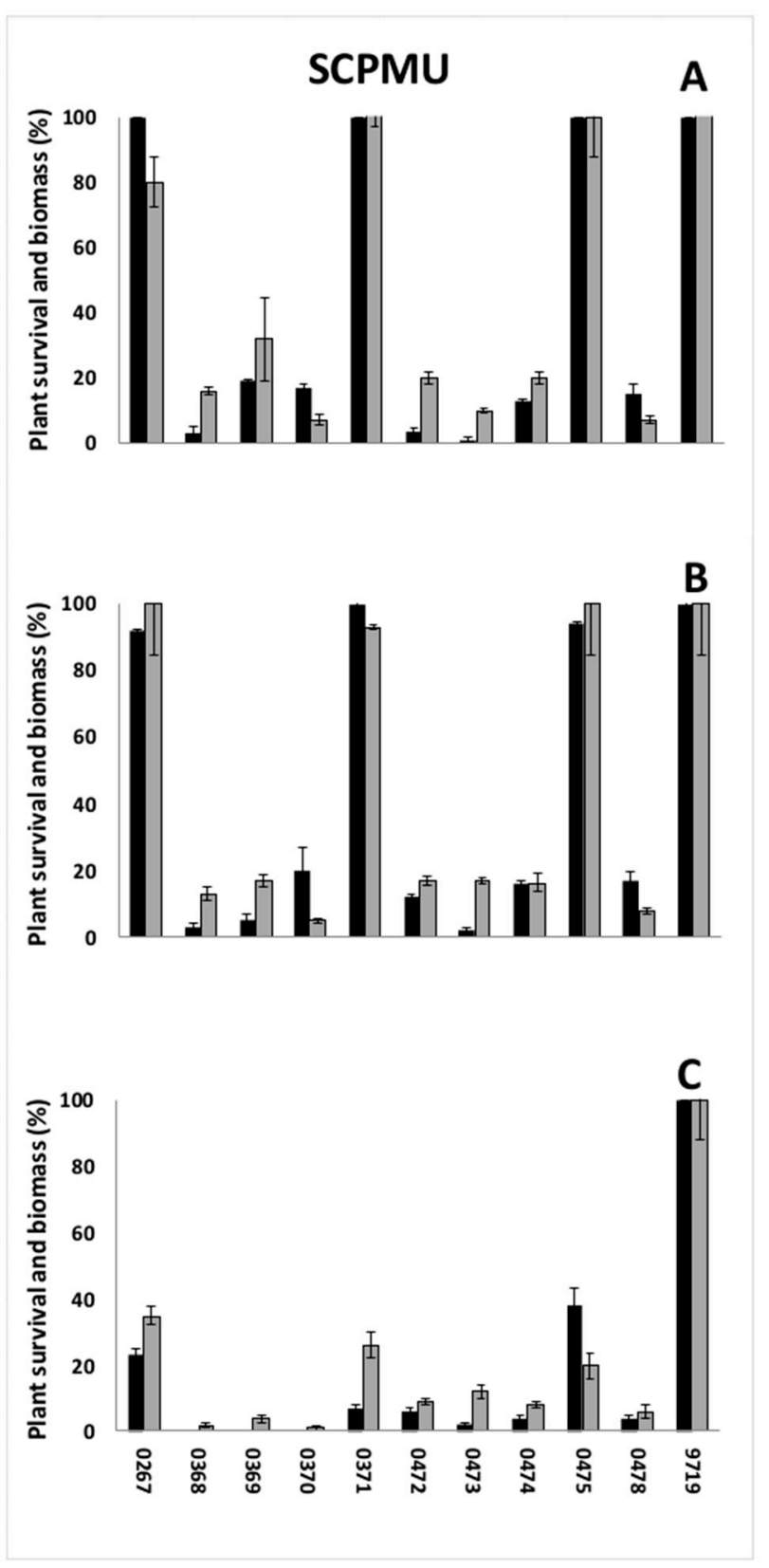

Figure 3. Sensitivity of populations of Schoenoplectus mucronatus (SCPMU) to three ALS inhibitors, azimsulfuron (A), bensulfuron-methyl (B), applied at full label dose corresponding to 20 and $60 \mathrm{~g}_{\text {ai ha }}{ }^{-1}$, respectively, and penoxsulam (C), applied at half the full label dose, corresponding to $20 \mathrm{~g}$ ai ha ${ }^{-1}$. Populations 9719 and 0267 are ALS-resistant checks. Values of survival (black bars) and biomass (grey bars) are expressed as percentage of the untreated control. Vertical bars represent standard errors.

Statistical analysis of the susceptible populations revealed that, within each species, the curves fitted for both "traits" were not parallel, and therefore $\mathrm{ED}_{50}$ or $\mathrm{GR}_{50}$ alone does not explain the overall variability. $\mathrm{ED}_{80}$ and $\mathrm{ED}_{90}$ as well as $\mathrm{GR}_{80}$ and $\mathrm{GR}_{90}$ were then also calculated, however $\mathrm{ED}_{90}$ and $\mathrm{GR}_{90}$ were not considered because of their relatively high variability in the analysis to calculate an average value for each species and to assess the range of intra-specific variability. Overall, GR values were lower than ED The intra-specific variability regarding EDs, GRs, and curve slopes (data not shown) among populations was relatively low in all three weeds, with no apparent effect of the population origin (i.e., country or cultivated/uncultivated sampling site). Regardless of species, all SU-susceptible 
populations were very well controlled by penoxsulam, and even all $\mathrm{ED}_{90}$ were well below half of the label dose (Figures 4-6). GRs of C. difformis and S. mucronatus were even lower, with $\mathrm{GR}_{80}$ and $\mathrm{GR}_{90}$ ranging below one-fourth of the recommended field dose of penoxsulam (i.e., $40 \mathrm{~g}$ ai ha ${ }^{-1}$ ). Variability among and within replicates for A. plantago-aquatica was again rather high, especially for fresh weight data, so only EDs values for plant survival are reported (Figure 4). The average $\mathrm{ED}_{50}, \mathrm{ED}_{80}, \mathrm{GR}_{50}$, and $\mathrm{GR}_{80}$ values estimated for the three species using a bootstrap procedure and considering only the populations still susceptible to ALS inhibitors, were clearly lower than the recommended field dose of penoxsulam ( $40 \mathrm{~g}_{\mathrm{gi} \mathrm{ha}}{ }^{-1}$ ), ranging from 1.4 to $8.4 \mathrm{~g}$ ai ha ${ }^{-1}$ (Table 2).

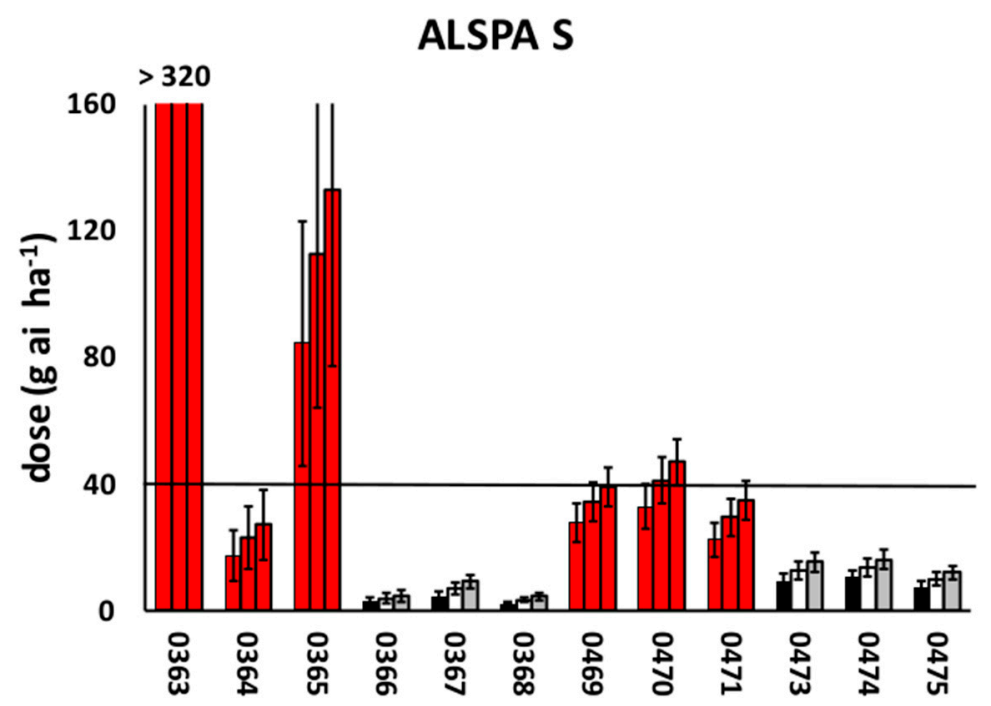

Figure 4. Estimation of $\mathrm{ED}_{50}, \mathrm{ED}_{80}$, and $\mathrm{ED}_{90}$ ( $\mathrm{ED}_{50}$ black bars, $\mathrm{ED}_{80}$ white bars and $\mathrm{ED}_{90}$ grey bars) of penoxsulam for plant survival (S) of populations of Alisma plantago-aquatica (ALSPA). Red bars indicate populations resistant to SUs according to the preliminary screenings. Population 0363 is an ALS-resistant check. Vertical bars represent 95\% Confidence Intervals. Recommended field dose of penoxsulam $\left(40 \mathrm{~g}_{\text {ai }} \mathrm{ha}^{-1}\right)$ is represented by the horizontal black line.

Table 2. Values of effective dose for $50 \%$ and $80 \%$ estimated plant survival $\left(E_{50}\right.$ and $\left.E_{80}\right)$ and fresh biomass reduction ( $\mathrm{GR}_{50}$ and $\mathrm{GR}_{80}$ ) of Alisma plantago-aquatica (ALSPA), Cyperus difformis (CYPDI), and Schoenoplectus mucronatus (SCPMU).

\begin{tabular}{|c|c|c|c|c|c|c|}
\hline & \multicolumn{3}{|c|}{$\mathrm{ED}_{50}$ or $\mathrm{GR}_{50} \mathrm{~g}$ ai ha $\mathrm{a}^{-1}$} & \multicolumn{3}{|c|}{$\mathrm{ED}_{80}$ or $\mathrm{GR}_{80} \mathrm{~g}$ ai ha ${ }^{-1}$} \\
\hline & Average & Confi & terval & Average & Confic & terval \\
\hline Plant survival & 6.0 & 3.6 & 8.4 & 8.4 & 5.2 & 11.6 \\
\hline $\begin{array}{c}\text { CYPDI } \\
\text { Plant survival } \\
\text { Fresh biomass }\end{array}$ & $\begin{array}{l}6.5 \\
2.6\end{array}$ & $\begin{array}{l}4.9 \\
2.4\end{array}$ & $\begin{array}{l}8.1 \\
2.8\end{array}$ & $\begin{array}{l}7.6 \\
3.8\end{array}$ & $\begin{array}{l}6.0 \\
3.5\end{array}$ & $\begin{array}{l}9.2 \\
4.1\end{array}$ \\
\hline $\begin{array}{c}\text { SCPMU } \\
\text { Plant survival } \\
\text { Fresh biomass }\end{array}$ & $\begin{array}{l}6.1 \\
1.4\end{array}$ & $\begin{array}{l}3.7 \\
0.9\end{array}$ & $\begin{array}{l}8.5 \\
1.9\end{array}$ & $\begin{array}{l}7.8 \\
3.1\end{array}$ & $\begin{array}{l}4.8 \\
2.1\end{array}$ & $\begin{array}{c}10.8 \\
4.1\end{array}$ \\
\hline
\end{tabular}

Average values and 95\% Confidence Intervals presented here were estimated with a bootstrap procedure and considering only the populations that are still susceptible to ALS inhibitors. 

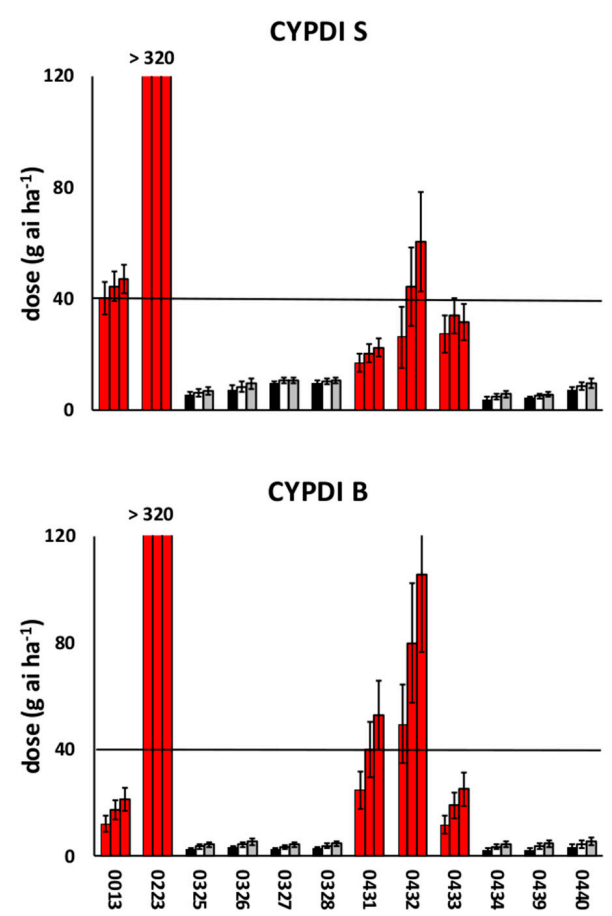

Figure 5. Estimation of $\mathrm{ED}_{50}, \mathrm{ED}_{80}$, and $\mathrm{ED}_{90}\left(\mathrm{ED}_{50}\right.$ and $\mathrm{GR}_{50}$ black bars, $\mathrm{ED}_{80}$, and $\mathrm{GR}_{80}$ white bars and $\mathrm{ED}_{90}$ and $\mathrm{GR}_{90}$ grey bars) of penoxsulam for plant survival (S) and fresh biomass reduction (B) of populations of Cyperus difformis (CYPDI). Red bars indicate populations resistant to sulfonylureas (SUs) according to the preliminary screenings. Populations 0013 and 0223 are ALS-resistant checks. Vertical bars represent $95 \%$ Confidence Intervals. Recommended field dose of penoxsulam $\left(40 \mathrm{~g}_{\text {ai ha }}{ }^{-1}\right)$ is represented by the horizontal black line.
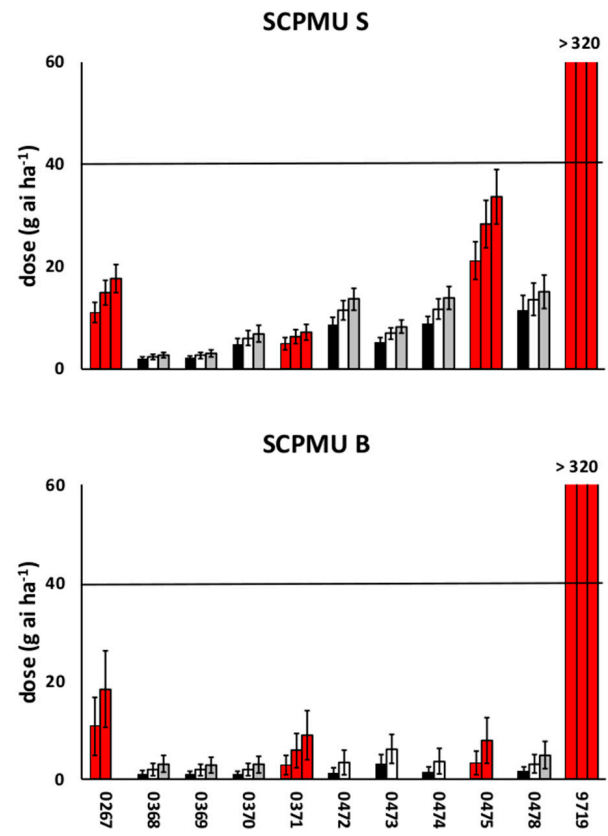

Figure 6. Estimation of $\mathrm{ED}_{50}, \mathrm{ED}_{80}$, and $\mathrm{ED}_{90}\left(\mathrm{ED}_{50}\right.$ and $\mathrm{GR}_{50}$ black bars, $\mathrm{ED}_{80}$, and $\mathrm{GR}_{80}$ white bars and $\mathrm{ED}_{90}$ and $\mathrm{GR}_{90}$ grey bars) of penoxsulam for plant survival (S) and fresh biomass reduction (B) of populations of Schoenoplectus mucronatus (SCPMU). Red bars indicate populations resistant to SUs according to the preliminary screenings. Populations 9719 and 0267 are ALS-resistant checks. Due to high variability, GR 90 of populations 0267 0472, 0473, 0474, and 0475 are not reported. Vertical bars represent $95 \%$ Confidence Intervals. Recommended field dose of penoxsulam $\left(40 \mathrm{~g}\right.$ ai ha $\left.{ }^{-1}\right)$ is represented by the horizontal black line. 


\section{Discussion}

Overall, the experiments with A. plantago-aquatica were less reliable due to the high variability between replicates. This was because of relevant differences in biomass accumulation and growth rate naturally occurring between individuals of this species (Sattin, personal communication), likely due to the extremely small seed size, with a 1000 seed weight lower than $0.5 \mathrm{~g}$ [27]. The efficacy of penoxsulam was affected by the previously evolved herbicide resistance selected by herbicides having the same SoA, i.e., ALS-inhibitors; several populations of the three species can indeed be considered to be cross-resistant to penoxsulam, azimsulfuron, and bensulfuron-methyl or at least as shifting towards this situation. However penoxsulam generally showed a higher efficacy than SUs. Good control levels were observed even on some SU-resistant $A$. plantago-aquatica, C. difformis, and S. mucronatus populations, confirming what was previously reported by Tabacchi et al. [28]. These SU-resistant populations are probably characterized by point mutations in the ALS gene that confer resistance to SUs but not to penoxsulam due to the partially different binding-site of triazolopyrimidines sulphonamides. Different point mutations or even different amino acid substitutions can confer different patterns of cross-resistance to the different groups of ALS-inhibitors (e.g., sulfonylureas (SU), imidazolinones (IMI), triazolopyrimidines sulphonamides (TP), pyrimidinylbenzoates (PB), and sulfonylaminocarbonyltriazolinones (SCT)), as widely reported for several weed species by Tranel et al. [29]. Calha et al. [30] described cross-resistance to the SUs azimsulfuron, bensulfuron-methyl, cinosulfuron, and ethoxysulfuron, but not to imazethapyr (IMI) for A. plantago-aquatica populations collected in rice paddy fields in Portugal. Different patterns of cross-resistance to ALS-Inhibitors were also reported for Italian, North American, and Spanish populations of $C$. difformis $[5,7,31,32]$, ranging from populations that are resistant only to SU to others cross-resistant to the SUs bensulfuron-methyl, halosulfuron-methyl, orthosulfamuron, imazethapyr (IMI), bispyribac-sodium (PB), penoxsulam (TP), and propoxycarbazonesodium (SCT) [7]. Similarly, previous studies reported $S$. mucronatus populations having different patterns of cross-resistance in Italy, USA and Chile [8,31,33]). Two point mutations of ALS gene (Pro197 to His and Trp574 to Leu) are more frequently reported as endowing resistance to ALS-inhibitors but with a different cross-resistance pattern. Pro197 to His is often associated to resistance to SU but low or moderate to IMI or TP, while Trp574 to Leu confers broad cross-resistance to different ALS-inhibitor groups [8,33-36]. However, Pro197 to His has recently been detected in an American C. difformis population that is characterized by a cross-resistance to bispyribac-sodium (PB), halosulfuron (SU), imazamox (IMI), and penoxsulam (TP) [32], so the level of homozygosis for this point mutation in a given individual can probably influence the level and pattern of resistance to ALS-inhibitors. Since different levels of ploidy (diploid and tetraploid) have been reported for C. difformis [36-38], the existence of multiple copies of ALS genes could also contribute to modify the pattern and level of resistance conferred by a specific point mutation.

Different point mutations, or different amino acidic substitution for the same mutation site endowing herbicide resistance, can be present within the same population or in a certain cropping area $[39,40]$, therefore resistance level and pattern at the population level depend on the frequency of the various resistant genotypes at that moment. The difference in sensitivity to penoxsulam of the SU-resistant populations included in this study could be related to the diverse presence and frequency of point mutations endowing different resistance patterns, such as Pro197 to His and Trp574 to Leu. Populations presenting relevant cross-resistance to SU and penoxsulam (i.e., ALSPA 0363, CYPDI 0223, and SCPMU 9719) probably have a high frequency of genotypes with mutation Trp574 to Leu, and this was reported for population SCPMU 9719 in a previous study [8]. Populations that are highly SU-resistant but susceptible to penoxsulam (i.e., ALSPA 0364, CYPDI 0433, SCPMU 0267 and 0371) are instead mainly composed of genotypes with mutation Pro197 to His. The presence and frequency within a given population of point mutations endowing ALS resistance is a consequence of the previous exposure to ALS-inhibitors but it is also continuously evolving according to the selection that is caused by current herbicide use and other control tools. Genotypes with point mutations conferring resistance 
to penoxsulam, such as Trp574 to Leu, can therefore be progressively selected due to repeated use of this herbicide even within populations that are currently still susceptible, and the increase in frequency of these genotypes will finally lead to a situation of cross-resistance to all ALS-inhibitor families.

Considering the EDs and GRs values of A. plantago-aquatica, C. difformis, and S. mucronatus susceptible populations, there seem to be no significant differences among various origins, although the limited number of populations does not allow final conclusions to be drawn. The sensitivity analysis reveals that penoxsulam was very effective in controlling all SU-susceptible populations with $\mathrm{ED}_{90}$ values well below half the label dose. Consequently, the average values of $\mathrm{ED}_{50,80}$ and $\mathrm{GR}_{50,80}$ estimated for the three species were lower than $20 \mathrm{~g}_{\text {ai ha }}{ }^{-1}$, even considering that the upper limit of confidence intervals at $95 \%$. This is in keeping with Merotto et al. [7] who estimated a value of $\mathrm{GR}_{50}$ around $9 \mathrm{~g}$ ai ha ${ }^{-1}$ for a susceptible North American C. difformis population. The artificial re-sampling method using the bootstrap procedure can therefore provide an effective and robust method to assess the average sensitivity to a given herbicide and the intra-specific variability based on a relatively small number of herbicide susceptible populations.

The average values of $\mathrm{ED}_{50,80}$ and $\mathrm{GR}_{50,80}$ estimated for the three species can be adopted as a reference to evaluate the susceptibility status of other populations, i.e., if a population has an ED or GR value higher than the average (plus confidence interval) then this population could be considered as evolving resistance. It would therefore be possible to promptly evaluate the shifting of susceptibility to penoxsulam, before it is clearly detectable under field conditions, and take action to limit the evolution of weed populations that are resistant to this herbicide. These findings are also useful to select appropriate populations as susceptible checks to determine the resistance level of further putative penoxsulam resistant populations. Selecting highly susceptible populations, i.e., those with notably lower ED or GR values than the estimated averages, could lead to an overestimation of the resistance level of putative resistant populations, since the Resistance Index is usually calculated as the ratio $\mathrm{ED}_{50} \mathrm{R} / \mathrm{ED}_{50} \mathrm{~S}$.

Supplementary Materials: The following are available online at http:/ / www.mdpi.com/2073-4395/8/10/220/s1, Spreadsheet S1: data of preliminary screenings; http:/ / www.mdpi.com/2073-4395/8/10/220/s2, Spreadsheet S2: data of EDs and GRs estimation.

Author Contributions: Conceptualization, B.C. and M.S.; Data curation, D.L., B.C. and M.S.; Formal analysis, D.L., P.K., B.C. and M.S.; Funding acquisition, N.D.V. and M.S.; Investigation, B.C. and M.S.; Project administration, N.D.V. and M.S.; Resources, N.D.V.; Supervision, M.S.; Visualization, D.L. and B.C.; Writing-original draft, D.L. and M.S.; Writing—-review \& editing, D.L., P.K., B.C., N.D.V. and M.S.

Funding: The research was jointly funded by the National Research Council of Italy (CNR) and DOW Agrosciences.

Acknowledgments: The authors are grateful to Alison Garside for revising the English text.

Conflicts of Interest: The research was partly funded by Dow Agrosciences, which is the patent owner of penoxsulam and is currently selling commercial products containing this active ingredient. Natalino Dalla Valle is an employee of Dow Agrosciences. However, data collection, analysis and interpretation were done independently by the authors belonging to public research institutions (Donato Loddo, Per Kudsk, Bruno Costa and Maurizio Sattin) who declare no conflicts of interest.

\section{References}

1. Heap, I. International Survey of Herbicide Resistant Weeds. Available online: www.weedscience.org (accessed on 30 July 2018).

2. GIRE-Italian Herbicide Resistance Working Group—Database of Herbicide Resistance in Italy. Available online: www.resistenzaerbicidi.it (accessed on 30 July 2018).

3. Sattin, M.; Berto, D.; Zanin, G.; Tabacchi, M. Resistance to ALS inhibitors in rice in north-western Italy. In Proceedings of the British Crop Protection Conference-Weeds, Brighton, UK, 15-18 November 1999; pp. $783-790$.

4. Sattin, M. Herbicide resistance in Europe: An overview. In Proceedings of the BCPC International Congress-Crop Science \& Technology, Glasgow, UK, 31 October-2 November 2005; pp. 131-138. 
5. Osuna, M.D.; Vidotto, F.; Fischer, A.J.; Bayer, D.E.; de Prado, R.; Ferrero, A. Cross-resistance to bispyribac-sodium and bensulfuron-methyl in Echinochloa phyllopogon and Cyperus difformis. Pest. Biochem. Physiol. 2002, 73, 9-17. [CrossRef]

6. Kuk, Y.I.; Kim, K.H.; Kwon, O.D.; Lee, D.J.; Burgos, N.R.; Jung, S.; Guh, J.O. Cross-resistance pattern and alternative herbicides for Cyperus difformis resistant to sulfonylurea herbicides in Korea. Pest. Manag. Sci. 2004, 60, 85-94. [CrossRef] [PubMed]

7. Merotto, A., Jr.; Jasieniuk, M.; Osuna, M.D.; Vidotto, F.; Ferrero, A.; Fischer, A.J. Cross-resistance to herbicides of five ALS-inhibiting groups and sequencing of the ALS gene in Cyperus difformis L. J. Agric. Food Chem. 2009, 57, 1389-1398. [CrossRef] [PubMed]

8. Scarabel, L.; Locascio, A.; Furini, A.; Sattin, M.; Varotto, S. Characterisation of ALS genes in the polyploid species Schoenoplectus mucronatus and implications for resistance management. Pest. Manag. Sci. 2010, 6, 337-344. [CrossRef] [PubMed]

9. Panozzo, S.; Scarabel, L.; Tranel, P.J.; Sattin, M. Target-site resistance to ALS inhibitors in the polyploid species Echinochloa crus-galli. Pest. Biochem. Physiol. 2013, 105, 93-101. [CrossRef]

10. Scarabel, L.; Cenghialta, C.; Manuello, D.; Sattin, M. Monitoring and management of imidazolinone-resistant red rice (Oryza sativa L., var. sylvatica) in Clearfield®Italian paddy rice. Agronomy 2012, 2, 371-383. [CrossRef]

11. EPPO (European and Mediterranean Plant Protection Organization). Efficacy evaluation of plant protection products. Resistance risk analysis. PP1/213 (3). EPPO Bull. 2015, 45, 371-387. [CrossRef]

12. Espeby, L.A.; Fogelfors, H.; Milberg, P. Susceptibility variation to new and established herbicides: Examples of inter-population sensitivity of grass weeds. Crop Prot 2011, 30, 429-435. [CrossRef]

13. Beckie, H.J.; Tardif, F.J. Herbicide cross resistance in weeds. Crop Prot. 2012, 35, 15-28. [CrossRef]

14. De Mol, F.; Gerowitt, B.; Kaczmarek, S.; Matysiak, K.; Sønderskov, M.; Mathiassen, S.K. Intraregional and inter-regional variability of herbicide sensitivity in common arable weed populations. Weed Res. 2015, 55, 370-379. [CrossRef]

15. Duke, S.O. Why have no new herbicide modes of action appeared in recent years? Pest. Manag. Sci. 2011, 68, 505-512. [CrossRef] [PubMed]

16. Rotteveel, T.; Jorgensen, L.N.; Heimbach, U. Resistance management in Europe: A preliminary proposal for the determination of a minimum number of active substances necessary to manage resistance. OEPP/EPPO Bull. 2011, 41, 432-438. [CrossRef]

17. Kudsk, P. Optimising herbicide dose: A straightforward approach to reduce the risk of side effects of herbicides. Environmentalist 2008, 28, 49-55. [CrossRef]

18. McDougall, P. The Global Agrochemical Market Trends by Crop. In Proceedings of the 11th China International Forum on Development of Pesticide Industry, Shanghai, China, 28 February 2017; Available online: http:/ / www.cac-conference.com/Uploads/Editor/2017-03-07/58be2c387de29.pdf (accessed on 15 June 2018).

19. Larelle, D.; Mann, R.K.; Cavanna, S.; Bernes, R.; Duriatti, A.; Mavrotas, C. Penoxsulam, a new broad spectrum rice herbicide for weed control in European Union paddies. In Proceedings of the BCPC International Congress-Crop Science \& Technology, Glasgow, UK, 10-12 November 2003; Volume 1, pp. 75-80.

20. Yasuor, H.; Osuna, M.D.; Ortiz, A.; Saldain, N.E.; Eckert, J.W.; Fischer, A.J. Mechanism of resistance to penoxsulam in late watergrass [Echinochloa phyllopogon (Stapf) Koss.]. J. Agric. Food Chem. 2009, 57, 3653-3660. [CrossRef] [PubMed]

21. Scarabel, L.; Berto, D.; Sattin, M. Dormancy breaking and germination of Alisma plantago-aquatica and Scirpus mucronatus. Asp. Appl. Biol. 2003, 69, 285-292.

22. Sattin, M.; Gasparetto, M.A.; Campagna, C. Situation and management of Avena sterilis ssp ludoviciana and Phalaris paradoxa resistant to ACCase inhibitors in Italy. In Proceedings of the BCPC Conference: Weeds, Brighton, UK, 13-15 November 2001; pp. 755-762.

23. Hess, M.; Barralis, G.; Bleiholder, H.; Buhr, L.; Eggers, T.; Hack, H.; Stauss, R. Use of the extended BBCH scale-General for the descriptions of the growth stages of mono- and dicotyledonous weed species. Weed Res. 1997, 37, 433-441. [CrossRef]

24. Panozzo, S.; Scarabel, L.; Collavo, A.; Sattin, M. Protocols for robust herbicide resistance testing in different weed species. J. Vis. Exp. 2015, 101, e52923. [CrossRef] [PubMed] 
25. Ritz, C. Toward a unified approach to dose-response modeling in ecotoxicology. Environ. Toxicol. Chem. 2010, 29, 220-229. [CrossRef] [PubMed]

26. Efron, B. The bootstrap and modern statistics. J. Am. Stat. Assoc. 2000, 95, 1293-1296. [CrossRef]

27. Zhang, J.; Yang, W.; Chen, X.; Liu, W.; Zhang, S.; Shu, Y. Studies on shapes and germination characters of Alisma plantago-aquatica seeds. Zhongguo Zhongyao Zazhi 2009, 34, 26-29. [PubMed]

28. Tabacchi, M.; Scarabel, L.; Sattin, M. Herbicide resistance in Italian rice crops: A late-developing but a fast-evolving story. In Proceedings of the Conference Challenges and Opportunities for Sustainable Rice-Based Production Systems, Torino, Italy, 13-15 September 2004; pp. 227-238.

29. Tranel, P.J.; Wright, T.R.; Heap, I.M. Mutations in Herbicide-Resistant Weeds to ALS Inhibitors. Available online: http:/ / www.weedscience.com (accessed on 30 July 2018).

30. Calha, I.M.; Osuna, M.D.; Serra, C.; Moreira, I.; De Prado, R.; Rocha, F. Mechanism of resistance to bensulfuron-methyl in Alisma plantago-aquatica biotypes from Portuguese rice paddy fields. Weed Res. 2007, 47, 231-240. [CrossRef]

31. Busi, R.; Vidotto, F.; Fischer, A.J.; Osuna, M.D.; De Prado, R.; Ferrero, A. Patterns of resistance to ALS herbicides in smallflower umbrella sedge (Cyperus difformis) and ricefield bulrush (Schoenoplectus mucronatus). Weed Technol. 2006, 20, 1004-1014. [CrossRef]

32. Tehranchian, P.; Riar, D.S.; Norsworthy, J.K.; Nandula, V.; McElroy, S.; Chen, S.; Scott, R.C. ALS-resistant smallflower umbrella sedge (Cyperus difformis) in Arkansas rice: Physiological and molecular basis of resistance. Weed Sci. 2015, 63, 561-568. [CrossRef]

33. Cruz-Hipolito, H.; Osuna, M.D.; Vidal, R.A.; de Prado, R. Resistance mechanism to bensulfuron-methyl in biotypes of Scirpus mucronatus L. collected in Chilean rice fields. J. Agric. Food Chem. 2009, 57, 4273-4278. [CrossRef] [PubMed]

34. Uchino, A.; Ogata, S.; Kohara, H.; Yoshida, S.; Yoshioka, T.; Watanabe, H. Molecular basis of diverse responses to acetolactate synthase-inhibiting herbicides in sulfonylurea-resistant biotypes of Schoenoplectus juncoides. Weed Biol. Manag. 2007, 7, 89-96. [CrossRef]

35. Sada, Y.; Ikeda, H.; Kizawa, S. Resistance levels of sulfonylurea-resistant Schoenoplectus juncoides [Roxb.] Palla having various Pro197 mutations in acetolactate synthase to imazosulfuron, bensulfuron-methyl, metsulfuronmethyl and imazaquin-ammonium. Weed Biol. Manag. 2013, 13, 53-61. [CrossRef]

36. Tehranchian, P.; Norsworthy, J.K.; Nandula, V.; McElroy, S.; Chenc, S.; Scott, R.C. First report of resistance to acetolactate-synthase-inhibiting herbicides in yellow nutsedge (Cyperus esculentus): Confirmation and characterization. Pest. Manag. Sci. 2015, 71, 1274-1280. [CrossRef] [PubMed]

37. Tejavathi, D.H.; Nijalingappa, B.H.M. Cytological studies in some members of Cyperaceae. Cytologia 1990, 55, 363-372. [CrossRef]

38. Cheema, P.; Bir, S.S. Cytomorphological studies in Cyperus Linn. V. Section Cyperus Linn. From Punjab, NW India; Indian Science Congress Association: Kolkata, India, 1995; Volume 82, pp. 82-83.

39. Merotto, A., Jr.; Jasieniuk, M.; Fischer, A.J. Distribution and cross-resistance patterns of ALS-inhibiting herbicide resistance in smallflower umbrella sedge (Cyperus difformis). Weed Sci. 2010, 58, 22-29. [CrossRef]

40. Sada, Y.; Kizawa, S.; Ikeda, H. Varied occurrence of diverse sulfonylurea-resistant biotypes of Schoenoplectus juncoides [Roxb.] Palla in Japan, as classified by an acetolactate synthase gene mutation. Weed Biol. Manag. 2012, 12, 168-176. [CrossRef]

(C) 2018 by the authors. Licensee MDPI, Basel, Switzerland. This article is an open access article distributed under the terms and conditions of the Creative Commons Attribution (CC BY) license (http://creativecommons.org/licenses/by/4.0/). 